\title{
Pomorski Krajowy Zakład dla Głuchoniemych w Wejherowie w latach 1921-1939. Wprowadzenie do badań
}

\begin{abstract}
Pomeranian National Institute for the Deaf and Mute in Wejherowo in 1921-1939. An Introduction to Research

In the interwar period there was an intensive development of the theory and practice of pedagogy in Poland. At that time new schools and centers for children with disabilities were created, including for the deaf-mute. In 1921 the Pomeranian National Institute for the deaf and mute was established in Wejherowo. The paper presents the circumstances of the institution's creation, its organization, rules of admission for pupils, curriculum and social life. Also provided is information on the authority of the Department and the teaching staff. In order to discuss these issues, source materials, stored in the Gdynia branch of the State Archive in Gdansk and held by the Educational-Instructional Centre for the Deaf Mute No. 2 in Wejherowo were used.
\end{abstract}

Keywords: history of special education, education and upbringing of the deaf and mute

Szkolnictwo dla głuchoniemych jest najstarszym działem szkolnictwa specjalnego w Polsce. Wiąże się z założeniem w Warszawie w 1817 r. Warszawskiego Instytutu Głuchoniemych, pierwszej placówki kształcącej dzieci głuche na ziemiach polskich. W roku 1842 przekształcono go w placówkę kształcącą także niewidomych i od tego czasu nosi nazwę Warszawskiego Instytutu Głuchoniemych i Ociemniałych. Jeszcze w XIX w., w ślad za instytucją warszawską, powstały na ziemiach polskich kolejne placówki o tym charakterze. Rozwój szkolnictwa specjalnego i pedagogiki specjalnej najintensywniej nastąpił w okresie dwudziestolecia międzywojennego, dzięki staraniom wybitnych pedagogów i działaczy oświatowych z Marią Grzegorzewską na czele. Wtedy też rozpoczął swoją działalność Państwowy Instytut Pedagogiki Specjalnej, pierwsza instytucja kształcąca pedagogów na potrzeby szkolnictwa specjalnego. Nie znaczy to jednak, że w dwudziestoleciu międzywojennym można było mówić o zaspokojeniu rzeczywistych potrzeb w zakresie kształcenia niepełnosprawnych. Oficjalną statystykę głuchoniemych w Polsce 
sporządzono dopiero w 1927 r., więc wszystkie wcześniejsze dane są tylko szacunkowe. Dane statystyczne, według Rocznika Statystycznego Rzeczypospolitej Polskiej z roku 1927 wskazują, że w Polsce było wówczas ogółem 33866 głuchoniemych, w tym 15018 kobiet i 18848 mężczyzn ${ }^{1}$. Tym czasem z danych dotyczących szkolnictwa wynika, że w roku szkolnym 1918/19 funkcjonowało w Polsce siedem szkół dla dzieci głuchoniemych, w których uczyło się 503 wychowanków i pracowało 65 nauczycieli². Natomiast sześć lat później, w 1925 r., w szkołach i zakładach dla niesłyszących uczyło się zaledwie 800 dziewcząt i chłopców na ogólną liczbę 4352 głuchoniemych dzieci w wieku szkolnym. Mogły się one kształcić w 11 placówkach, które funkcjonowały w Warszawie (Instytut Głuchoniemych i Ociemniałych, Szkoła Miejska Popołudniowa dla Głuchoniemych, Szkoła dla Głuchoniemych Towarzystwa Opieki nad Głuchoniemymi Żydami), we Lwowie (Zakład dla Głuchoniemych, Szkoła Prywatna Bardacha - dla dzieci żydowskich), w Poznaniu (Zakład Krajowy dla Głuchoniemych) i w Kościanie w województwie poznańskim (Zakład Krajowy dla Głuchoniemych), w Łodzi (Szkoła dla Głuchoniemych Chrześcijan nr 97, Szkoła Żydowska Towarzystwa Ezras-Ilmin), Wejherowie (Pomorski Krajowy Zakład dla Głuchoniemych) oraz w Willi-Górze koło Nowego Dworu (Państwowa Szkoła Rolniczo-Ogrodnicza dla Głuchoniemych) ${ }^{3}$. Do wybuchu II wojny światowej sytuacja niewiele się zmieniła. Jak podaje Henryk Ryll, istniało wówczas w Polsce tylko 16 placówek dla głuchoniemych, w których uczyło się 1333 dzieci, a zatrudniały one 121 nauczycieli ${ }^{4}$.

Pomorski Krajowy Zakład dla Głuchoniemych w Wejherowie był jedną z nielicznych szkół dla głuchoniemych, które funkcjonowały już w pierwszych latach po odzyskaniu przez Polskę niepodległości. Warto podkreślić, że instytucja działa w Wejherowie do chwili obecnej jako Ośrodek Szkolno-Wychowawczy nr 2 dla Głuchych im. J. Siestrzyńskiego. Jednakże placówka ta nie doczekała się jeszcze pełnego monograficznego opracowania. Dlatego też niniejsza publikacja jest przyczynkiem do badań nad dziejami tej instytucji oraz próbą opisania jej organizacji i działalności w latach międzywojennych. W tym celu wykorzystano materiały źródłowe zgromadzone w Archiwum Państwowym w Gdańsku Oddział w Gdyni, materiały okolicznościowe publikowane przez Ośrodek Szkolno-Wychowawczy dla Głuchych w Wejherowie, a także niepublikowane materiały, będące w posiadaniu Ośrodka.

Statystyka, „Nauczyciel Głuchoniemych i Niewidomych” 1928, nr 2, s. 28.

2 W. Tułodziecki, Stan i potrzeby szkolnictwa dla głuchoniemych $w$ Polsce, „Nauczyciel Głuchoniemych i Niewidomych" 1932, nr 1.

3 J. Hellmann, Stan i potrzeby szkolnictwa specjalnego w Polsce, „Szkoła Specjalna” 1924/25, nr 1, s. $6-7$.

${ }^{4}$ H. Ryll, Stan szkolnictwa specjalnego w Polsce w ostatnim pięcioleciu, „Szkoła Specjalna” 1938/39, nr 15 , s. $153-155$. 


\section{Powstanie Pomorskiego Krajowego Zakładu dla Głuchoniemych w Wejherowie}

Po I wojnie światowej niemieckie szkoły dla dzieci głuchych w Malborku i Człuchowie znalazły się poza granicami wyzwolonego państwa polskiego. Zaistniała więc potrzeba utworzenia szkoły dla głuchoniemych dzieci okręgu pomorskiego. Starostwo Krajowe w Toruniu podjęło decyzję o utworzeniu w dniu 1 września 1921 r. Pomorskiego Krajowego Zakładu dla Głuchoniemych z siedzibą w Wejherowie. Na lokal szkoły przeznaczono wydzielone budynki likwidowanego szpitala psychiatrycznego ${ }^{5}$. Szpital psychiatryczny został założony w 1883 r., natomiast po odzyskaniu niepodległości jego pierwszym polskim dyrektorem był dr Edward Kawczyński, który przejął w 1920 r. prawie pusty zakład. Władze niemieckie przeniosły bowiem chorych żołnierzy niemieckich oraz jeńców do innych zakładów, pozostawiając w Wejherowie obywateli polskich. Dlatego też Starostwo Krajowe w Toruniu, unikając oddania budynków szpitalnych na koszary, postanowiło uruchomić w nich inne placówki o charakterze opiekuńczym i wychowawczym. Realizację tych założeń rozpoczęto od organizacji Zakładu dla Głuchoniemych ${ }^{6}$. Protokół przejęcia kasy Zakładu dla Głuchoniemych przyjęto 13 grudnia 1921 r. Na majątek placówki składały się środki w gotówce w kwocie 95100 marek oraz na koncie 3739, co łącznie stanowiło sumę 98 842 marek $^{7}$. Przejęcie protokołem przez Zakład dla Głuchoniemych sprzętów, będących dotychczas własnością zakładu psychiatrycznego, nastąpiło 16 grudnia $1922 \mathrm{r}^{8}$

W dniu 1 stycznia 1923 r. dr Stanisław Gąsowski przejął od dyrektora Krajowego Zakładu Leczniczego dla Nerwowo Chorych, dr E. Kawczyńskiego, całe urzędowanie na czas likwidacji szpitala aż do czasu zakończenia działań związanych z organizacją Zakładu dla Głuchoniemych i innych planowanych instytucji (ociemniałych, kalek i anemicznych) w Wejherowie ${ }^{9}$. W tym też roku powołano Krajowe Zakłady Opieki Społecznej jako zespół instytucji zlokalizowany w Wejherowie przy ul. Sobieskiego. Zakłady były własnością Pomorskiego Wojewódzkiego Związku Komunalnego, podlegającego Samorządowi wojewódzkiemu, pod kontrolą Ministerstwa Spraw Wewnętrznych ${ }^{10}$. Stan Zakładów Opieki Społecznej zmieniał się w różnych okresach, a w jego skład obok Zakładu dla Głuchoniemych ostatecznie wchodziły: Zakład Leczniczy dla Nerwowo Chorych, Zakład Dzieci Syberyjskich, Pomorska Izba Rolnicza, Urząd Emigracyjny w Gdyni z tymczasową siedzibą w Wejherowie, Szkoła Podstawowa i Zakład Wychowawczy dla Moralnie Zaniedbanych oraz Szkoła Specjalna dla Dzieci Upośledzonych Umysłowo ${ }^{11}$.

${ }^{5}$ Historia Ośrodka Szkolno-Wychowawczego nr 2 dla Gtuchych im. J. Siestrzyńskiego w Wejherowie, Wejherowo 1991, s. 7.

${ }^{6}$ J. Kotewicz, Historia zakładu dla Gluchych $w$ Wejherowie. Maszynopis w posiadaniu Biblioteki Ośrodka Szkolno-Wychowawczego nr 2 w Wejherowie, knlb.

${ }^{7}$ Archiwum Państwowe w Gdańsku, Oddział w Gdyni (dalej APGOG), Zespół 223, Krajowe Zakłady Opieki Społecznej w Wejherowie, sygn. 9, k. 17.

8 Ibidem, k. 24.

9 Ibidem, k. 1-2.

${ }^{10}$ APGOG, Zespół 223, Krajowe Zakłady Opieki Społecznej w Wejherowie, sygn. 3, k. 145.

${ }^{11}$ Ośrodek Szkolno-Wychowawczy nr 2 dla Niestyszacych im. J. Siestrzyńskiego w Wejherowie, Wejherowo 2001, s. 11. 
W następnej kolejności uchwalono przez Sejmik Wojewódzki, w dniu 8 stycznia 1925 r., Regulamin dla Pomorskiego Krajowego Zakładu dla Głuchoniemych w Wejherowie, zatwierdzony dekretem Ministerstwa Spraw Wewnętrznych z dnia 27 kwietnia 1925 r. ${ }^{12}$ Regulamin określał wszystkie istotne aspekty funkcjonowania zakładu, jak: zakres działania, administracja, kadra i stosunki służbowe, działanie rady pedagogicznej, zasady przyjmowania wychowanków, program nauczania, opieka lekarska i wychowawcza czy koszty utrzymania. Zgodnie z zapisami Regulaminu Zakład dla Głuchoniemych był internatem, a jego nadrzędnym zadaniem było kształcenie $i$ wychowanie dzieci gtuchoniemych odpowiednio do ich zdolności umysłowych i przysposobienie ich do zawodowego kształcenia ${ }^{13}$. Administracyjnie zakład prowadził Wydział Krajowy (względnie Starosta Krajowy) według regulaminu oraz uchwał Sejmiku Wojewódzkiego. Państwową nadzorczą władzę szkolną nad placówką pełniło Kuratorium Okręgu Szkolnego Pomorskiego, do zadań którego należało przyjęcie programu i planu nauczania, nadzór nad nauczaniem i wychowaniem oraz wizytowanie i wspomaganie placówki w celu utrzymania właściwego poziomu naukowego. Bezpośredni nadzór nad instytucją spoczywał na dyrektorze, którego zadania określał sejmik Wojewódzki oraz instrukcja służbowa. Zadaniem dyrektora było utrzymywanie kontaktu ze Starostwem Krajowym, władzami powiatowymi i gminnymi, rodzicami wychowanków, z Urzędem Wojewódzkim, Kuratorium Okręgu Szkolnego Pomorskiego, a także Ministerstwem za pośrednictwem Starosty Krajowego ${ }^{14}$.

\section{Baza lokalowa}

Według dokumentów inwentarza budynków Zakładu z 1935 r. wynika, że w skład placówki wchodziły: Pawilon D, w którym mieściła się kaplica, pawilon 14, gdzie ulokowane były mieszkania nauczycieli oraz szpital dla wychowanków zakładu. W pawilonie 10 znajdował się internat dla głuchoniemych chłopców, a w pawilonie 12 był internat dla głuchoniemych dziewcząt. Szkoła została ulokowana w pawilonie 8, zaś warsztaty, stolarnie i introligatornia znajdowały się w pawilonie 2. Warto dodać, że pawilon 11 i 9 zajmowały internaty Zakładu Wychowawczego, a szkoła tego zakładu mieściła się w pawilonie 4. Natomiast w pawilonie 6 mieściła się szkoła i internat dla upośledzonych umysłowo. Na terenie zakładu mieściło się także boisko szkolne ${ }^{15}$. Pawilony nie bardzo nadawały się do celów szkolnych, gdyż miały mało okien, a rozkład dużych, przechodnich sal nie sprzyjał pracy wychowawczej ani rozwojowi fizycznemu dzieci. Blok 8, w którym mieściła się szkoła trzeba było adaptować do potrzeb dydaktycznych, dzieląc

12 Regulamin dla Pomorskiego Krajowego Zakładu dla Gluchoniemych w Wejherowie, Dziennik Urzędowy Województwa Pomorskiego, nr 15, rok V, Toruń, 13 VI, 1925.

13 Ibidem, s. 67.

14 Ibidem, s. 68.

15 APGOG, Zespół 223, Krajowe Zakłady Opieki Społecznej w Wejherowie, sygn.12, k. 131-136. 
sale na mniejsze izby lekcyjne. Mimo takich starań, cztery sale pozostały jako przejściowe. Ponadto pawilon szkolny nie posiadał sali rekreacyjnej ani sali gimnastycznej. Podczas przerw lekcyjnych dzieci przebywały w dni pogodne na dziedzińcu szkolnym, a w zimie i pozostałe dni pozostawały cały czas w salach lekcyjnych. Zajęcia gimnastyczne odbywały się na dziedzińcu szkolnym, a w okresie zimowym w sali gimnastycznej miejscowego gimnazjum ${ }^{16}$.

Bardzo proste i skromne było wyposażenie internatów: długie stoły i ławy w świetlicy i jadalni, żelazne łóżka i szafy w sypialniach. Pomieszczenia te były bardzo nieestetyczne, ciemne i ponure ${ }^{17}$.

\section{Przyjmowanie dzieci do Zakładu}

W pierwszym roku działalności do Zakładu przyjęto blisko 80 wychowanków. W kolejnych latach liczba dzieci przyjmowanych do placówki wzrastała i wynosiła około 120 uczniów ${ }^{18}$.

W Regulaminie Zakładu bardzo szczegółowo opisano zasady przyjmowania dzieci do placówki. Przyjmowano tu dzieci głuchonieme, posiadające orzeczenie o obowiązku uczęszczania do szkoły specjalnej. Przed przyjęciem dziecka do zakładu władze miejscowe na żądanie Starosty Krajowego powinny przedłożyć świadectwo urodzenia, świadectwo chrztu, świadectwo szczepienia ospy oraz wywiad urzędowy statystyczny. Przyjęcie dzieci następowało zazwyczaj z rozpoczęciem następnego roku szkolnego, ale Starosta Krajowy mógł wyznaczyć w wyjątkowych wypadkach inny termin. Starosta Krajowy mógł także z ważnych przyczyn zwolnić dziecko głuchonieme od obowiązku uczęszczania do zakładu, ale na okres najwyżej jednego roku. Decyzję odroczenia należało podać do wiadomości rodzicom lub opiekunom dziecka. Odpis decyzji otrzymywał także Kurator Okręgu Szkolnego. W materiałach archiwalnych znaleźć można potwierdzenie szczegółowego przestrzegania zasad podanych w regulaminie. Liczna, zgromadzona korespondencja władz lokalnych z dyrekcją Zakładu, rodzicami, lekarzami dotyczy głównie odroczeń od obowiązku szkolnego, zdrowia dzieci głuchoniemych, kosztów utrzymania czy zakwaterowania ${ }^{19}$. Polecenie odstawiania dziecka do zakładu otrzymywali rodzice lub opiekunowie co najmniej 6 tygodni przed terminem przyjęcia dziecka do placówki. Starosta Krajowy komunikował rodzicom lub opiekunom dziecka głuchoniemego termin umieszczenia dziecka w zakładzie, wzywając ich równocześnie do odstawienia dziecka w stanie czystym, z bielizną i odzieżą przepisaną regulaminem. Dyrektor zakładu mógł w porozumieniu z rodzicami lub opiekunami zarządzić dowiezienie dziecka do zakładu

\footnotetext{
16 J. Kotewicz, op. cit., knlb.

17 Historia Ośrodka..., s. 16.

${ }^{18}$ Ośrodek.., s. 16.

${ }^{19}$ APGOG, Zespół 72, Inspektorat Szkolny w Wejherowie z lat [1911] 1918-1939, sygn.343, t I i t II, passim.
} 
przez swój personel wychowawczy lub inne odpowiednie osoby. Jeżeli rodzice lub opiekunowie odmawiali umieszczenia wychowanka w zakładzie lub jeżeli dziecko w okresie 4 tygodni od wyznaczonego terminu przyjęcia do zakładu nie zostało w nim umieszczone, to Starosta Krajowy miał obowiązek wnieść do Kuratorium prośbę o przymusowe dowiezienie ucznia. Zakład dla Głuchoniemych najmłodszych wychowanków, tj. dzieci w wieku od 1 roku do 4 lat, obowiązkowo umieszczał w swoim internacie. Dzieci starsze umieszczano, jeśli to było możliwe, jako eksternistów u rodzin tego samego wyznania w najbliższej okolicy Zakładu. Osobno kwaterowano dziewczęta i osobno chłopców. Dyrekcja zakładu zasadniczo nie umieszczała w internacie dzieci mieszkające u rodziców w mieście a dochodzące do szkoły Zakładu oraz dzieci umieszczanych przez rodziców u obcych rodzin. Do umieszczenia dziecka u obcych rodzin potrzebna była zgoda dyrektora placówki, który musiał o tym fakcie poinformować Starostę Krajowego. Starosta Krajowy mógł cofnąć to zezwolenie, jeżeli okazałoby się, że dziecko dochodzące do placówki zaniedbuje się w nauce lub nieregularnie uczęszcza do szkoły. W takiej sytuacji dziecko było umieszczane w internacie lub rodzinie wybranej przez Zakład. Przy umieszczaniu dzieci w rodzinach uwzględniano często życzenia rodziców, jakie mieli oni względem opiekunów. Eksternistów umieszczano tylko w takich rodzinach, które dysponowały dostatecznym mieszkaniem i dawały pewność należytej opieki oraz wychowania w duchu religijnym, moralnym i narodowym. Dyrektor zakładu zawierał stosowną umowę z głową rodziny, u której dziecko miało mieszkać. W umowie tej dana rodzina zobowiązywała się do przyjęcia dziecka do grona rodzinnego, wychowywania go w duchu moralny, religijnym i narodowym. Zobowiązywała się także do udostępnienia odpowiedniego pomieszczenia z łóżkiem oraz zdrowego i wystarczającego wyżywienia, a w przypadku choroby do udzielenia dziecku należytej opieki. Rodzina przyjmująca pod opiekę dziecko głuchonieme zobowiązywała się także do przyuczania go do porządku i czystości oraz pilności i regularnego uczęszczania do szkoły. Dyrektor lub nauczyciele wyznaczeni przez dyrektora Zakładu mieli prawo przeprowadzania kontroli nad daną rodziną i wykonywaniem przez nią przyjętych obowiązków. Opłatę utrzymania dzieci w rodzinach ustanawiał Wydział Krajowy.

Dzieci przebywające w Zakładzie miały zapewnioną opiekę lekarską. Opiekę lub leczenie przez lekarzy specjalistów wychowankowie otrzymywali bezpłatnie, podobnie środki lecznicze przepisane przez lekarzy. Koszty leczenia pokrywał Zakład. W przypadkach ciężkiej choroby, wymagającej umieszczenia wychowanka w szpitalu lub lecznicy, decyzję o takim leczeniu podejmował Starosta Krajowy, po uzyskaniu opinii od lekarza prowadzącego oraz dyrektora Zakładu. W wypadkach nagłych dyrektor mógł sam, na podstawie opinii lekarza, zarządzić umieszczenie w szpitalu i prosić o niezwłoczne zatwierdzenie tej decyzji przez Starostę Krajowego. W przypadku śmierci wychowanka dyrektor miał obowiązek niezwłocznie powiadomić o tym fakcie rodziców lub opiekunów, urząd stanu cywilnego oraz Starostę Krajowego. Równocześnie dyrektor miał obowiązek czynić starania o pogrzeb, jeżeli o to nie troszczyli się rodzice dziecka. Koszty pogrzebu ponosiły osoby ustawowo do tego zobowiązane. O każdym przypadku śmierci Starosta Krajowy musiał powiadomić Kuratorium i Urząd Wojewódzki. 
Z wyjątkiem dzieci dochodzących, które nosiły własną odzież i bieliznę, wszyscy wychowankowie, interniści i eksterniści, otrzymywali jednolity ubiór zakładowy, bieliznę i obuwie, którą uzupełniano w każdym roku lub według potrzeby. Dzieci nowo przyjęte do zakładu przynosiły z domu odzież przepisaną regulaminem i nosiły ją aż do zużycia. Wszelkich napraw odzieży podejmował się Zakład, robiąc to we własnych pracowniach. Na wniosek rodziców lub opiekunów, zobowiązanych do utrzymania dzieci z własnego majątku, dyrektor Zakładu mógł udzielić zezwolenia na noszenie przez nie własnej odzieży i obuwia, pod warunkiem, że rodzice zobowiązali się utrzymać je we właściwym porządku. Takie zezwolenie mogło być przez dyrektora odwołane, jeśli rodzice nie dbali o wygląd dziecka. W przypadku przeprowadzenia się rodziny dziecka do innego województwa, rodzice mieli obowiązek zgłosić ten fakt Staroście Krajowemu. Ten z kolei czynił starania w sprawie umieszczenia dziecka w zakładzie odnośnego związku komunalnego. Przeniesienie dziecka do innego zakładu nastąpić mogło dopiero z końcem roku szkolnego. Uczeń mógł pozostać w Zakładzie tylko wtedy, gdy rodzice lub związek komunalny zobowiązał się do zwrotu kosztów. O przeniesieniu ucznia do innego zakładu Starosta Krajowy musiał powiadomić Kuratorium i Urząd Wojewódzki.

Koszty powstałe z obowiązkowego kształcenia dzieci głuchoniemych ponosił miejscowy związek ubogich siedziby wsparcia. Należały do nich koszty dostawienia dziecka do zakładu, koszty pierwszego wyekwipowania wychowanka, koszty pogrzebu oraz koszty podróży dziecka po zwolnieniu z placówki. Rodzice lub osoby zobowiązane według przepisów kodeksu cywilnego do utrzymywania dziecka powinny zwracać Zakładowi koszty mieszkania w zakładzie lub eksternacie, wyżywienia, odzieży, opieki lekarskiej, lekarstw lub pielęgnacji w szpitalu w ryczałtowej sumie 438 zł rocznie. Jeżeli osoby te nie mogły pokryć tych kosztów w całości lub częściowo, to koszty te ponosił miejscowy związek ubogich siedziby wsparcia. Żądane zwroty kosztów od związku ubogich oraz ich uregulowanie następowało za pośrednictwem danego wydziału powiatowego. Wydział powiatowy był zobowiązany udzielić związkowi ubogich zapomogi w wysokości co najmniej 3/4 rzeczywistych kosztów utrzymania dziecka w placówce. Natomiast koszty utrzymania ubogich dzieci krajowych ponosił Krajowy Związek Komunalny. Jeżeli dziecko uczęszczające do zakładu umieszczone zostało przez rodziców w prywatnym domu za zgodą dyrekcji, to koszty obniżane były do kwoty 98 zł rocznie. W przypadku dostarczania przez rodziców odzieży dla dziecka, koszty utrzymania spadały do kwoty 60 zł rocznie. Osoby nienależące do Pomorskiego Związku Komunalnego płaciły pełne stawki kosztów utrzymania i administracji Zakładu w wysokości 803 zł rocznie. Wydział Krajowy mógł obniżyć lub podnieść powyższe stawki w stosunku do oficjalnego wskaźnika drożyźnianego artykułów pierwszej potrzeby.

Regulamin zakładu zawierał pełne zestawienie odzieży, w które musiało być wyposażone dziecko. Dla chłopców przewidziano: 2 ubiory, 2 pary kalesonów, 2 kaftaniki, 1 nakrycie na głowę, 1 parę butów, 1 parę trzewików, 1 parę pantofli, 2 pary pończoch wełnianych, 2 pary pończoch bawełnianych, 3 koszule, 3 półkoszulki, 3 chusteczki do nosa, 2 chusteczki na szyję, 1 parę rękawiczek wełnianych, 1 parę szelek, 1 szczotkę do obuwia, 1 szczotkę do smarowidła, 1 grzebień, 1 szczoteczkę do zębów. 
Dziewczynki natomiast miały mieć przygotowane: 2 sukienki, 2 podstaniczki, 2 pary majtek, 2 spódnice, 1 kaftanik dzienny, 1 kaftanik nocny, 3 koszule, 1 nakrycie na głowę, 2 pary pończoch wełnianych, 2 pary pończoch bawełnianych, 3 fartuchy, 2 pary trzewików, 1 parę pantofli, 1 parę podwiązek, 2 chustki na szyję, 2 chustki do nosa, 1 parę rękawiczek wełnianych, 1 szczotkę do obuwia, 1 szczotkę do smarowidła, 1 grzebień, 1 szczoteczkę do zębów ${ }^{20}$.

\section{Kadra dydaktyczna i wychowawcy}

Zgodnie z zapisami Regulaminu Dyrektor oraz nauczyciele zatrudnieni w placówce musieli posiadać wymagane ustawą kwalifikacje ogólne i specjalne. Przy ustalaniu etatów nauczycieli należało się kierować koniecznością udzielania religii dzieciom katolickim i ewangelickim ${ }^{21}$.

Za całokształt funkcjonowania placówki, w tym za pracę dydaktyczną odpowiadał dyrektor. Pierwszym dyrektorem Zakładu był Leonard Retzlaff, który pełnił tę funkcje w latach 1921-1926. W początkowym okresie funkcjonowania placówki był jedynym nauczycielem posiadającym potrzebne kwalifikacje. Dlatego też obok zarządzania zakładem zajmował się także przygotowaniem nauczycieli do pracy z dziećmi z wadą słuchu. Jego zajęcia hospitowali wszyscy nauczyciele. Po hospitacjach odbywały się seminaria, na których wygłaszano związane z tematem referaty oraz prowadzono dyskusje. Intensywność i jakość tego typu samokształcenia spowodowały, że zgłoszono je w Instytucie Pedagogiki Specjalnej jako zaoczne studium kończące się egzaminem państwowym i nadaniem kwalifikacji do pracy w szkole dla głuchoniemych. L. Retzlaff znany był z surowości i zamiłowania do rygoru. Podobno te właśnie cechy charakteru stały się bezpośrednim powodem jego odejścia ze stanowiska dyrektora ${ }^{22}$. Potwierdza to J. Kotewicz, który w swoim monograficznym opracowaniu podaje, że nadmierna dyscyplina wprowadzona przez ówczesnego dyrektora, doprowadziła w 1927 r. do wysłania przez uczniów VII klasy listu z zażaleniem do Starostwa Krajowego. Fakt ten miał być powodem zmian na stanowisku dyrektora ${ }^{23}$. Funkcję dyrektora placówki po L. Retzlaffie przejął Franciszek Jereczek, pełniący ją w latach 1926-1933. Ostatnim dyrektorem placówki przed wybuchem wojny był ks. Józef Bartel, którego kadencja przypadła na lata 1933-1939. Żył w latach 1894-1955, był synem listonosza. Po ukończeniu seminarium duchownego w 1923 r. przyjął święcenia kapłańskie. W 1926 r. przyjął posadę prefekta i katechety w Zakładzie dla Głuchoniemych, a od roku 1933 pełnił obowiązki kierownika tej placówki. Był gorącym zwolennikiem metody werbalnej w nauczaniu niesłyszących. Posiadał kwalifikacje wymagane do nauczania dzieci głuchych. Ukończył studium

\footnotetext{
${ }^{20}$ Regulamin..., s. 68-70.

21 Ibidem, s. 68.

22 Ośrodek...., s. 16.

23 J. Kotewicz, op. cit., knlb.
} 


\section{PAŃSTWOWY INSTYTUT PEDAGOGIKI SPECJALNEJ. \\ W WARSZAWIE}

\section{DYPLOM}

\section{Nauczyciela gluchoniemych \\ Pan ficiforesti gren}

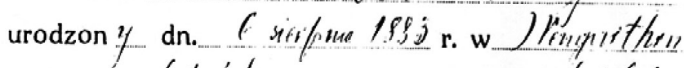

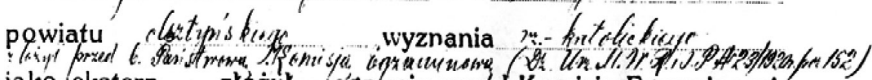

jako ekstem atoming

$\mathrm{z}$ wynikiem następującym:

1. Z pracy piśmierinej

2. $Z$ psychologii pedagogicznej

3. Z psychopatologi dziecka $z$ uwzględnieniem podstaw psychopatologii ególnej

4. $Z$ fonatyki i ortofonji Ilolerus

5. $Z$ mat dyki nouczania gluchoniemych d/ct: 6

6. $Z$ dziejów nauczania gluchoniemych dal-the

7. Z lekcyj egzaminacyjnych elofome

8. Ze slöjdu

9. Z gimnastyki, gier i zabaw

10. $Z$ rysunków

11. $Z$ rozprawy dyplomowej dositateen min.

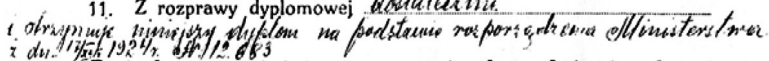

Swiadectwo niniejsze uprawnia do pelnienia obowiązków

nauczyciela Szkół Specjalnych dla dzieci głuchoniemych.

w Warszawie, dnia / Cherute _ 192 L.

Delegat Ministerstwa.

Przewo.tniczqcy Komisji, Egzaminacyjnej

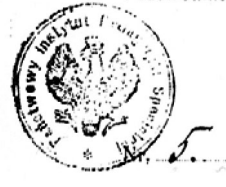

Dyrektor Instytutu

Pedagogiki Specjalnej

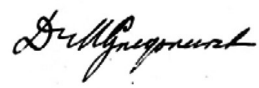

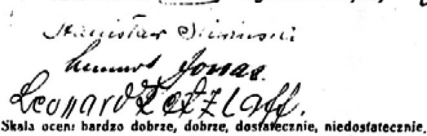

Ryc. 1. Dyplom Nauczyciela głuchoniemych

Źródło: Historia Ośrodka Szkolno-Wychowawczego nr 2 dla Gluchych im. J. Siestrzyńskiego $w$ Wejherowie, Wejherowo 1991, s. 9. 
kwalifikacyjne organizowane przez PIPS w Warszawie, gdzie zaprzyjaźnił się z Marią Grzegorzewską. W czasie wojny był więźniem obozów w Stutthofie i Mathausen ${ }^{24}$.

Pierwszymi nauczycielami w Zakładzie byli mężczyźni, absolwenci niemieckich seminariów nauczycielskich. Byli to: Jan Bieńkowski, Edmund Fenske, Józef Idzikowski, Teofil Lisakowski, Jan Maciejewski, Wojciech Wojczyński. Większość nauczycieli nie tylko nie znała metod pracy z dziećmi niesłyszącymi, ale wykazywała się słabą znajomością języka polskiego. Dokształcanie się w obu dziedzinach stało się więc koniecznością. Obowiązek ten przyjął na siebie ówczesny dyrektor placówki, L. Retzlaff. Pod koniec roku szkolnego 1921/22 zatrudniono pierwsza kobietę, Stefanię Wojciechowską ${ }^{25}$.

Według Kalendarza-Informatora Polskiego Związku Głuchych w roku szkolnym 1932/33 pracowało w szkole 13 nauczycieli pod kierownictwem ks. Józefa Bartla. W czasie wojny zginęło wielu nauczycieli i wychowawców. W 1939 r. w lasach piaśnickich zostali rozstrzelani ks. F. Niklewski, ówczesny dyrektor Krajowych Zakładów Opieki Społecznej, a wskutek represji okupanta zmarli, wysłani na przymusowe roboty Jan Bieńkowski i Stefania Wojciechowska, nauczyciele Zakładu dla Guchoniemych ${ }^{26}$. Pełny wykaz nauczycieli, wychowawców i pracowników Zakładu przedstawia tabela 1.

Tabela 1. Wykaz nauczycieli, wychowawców i pracowników

\begin{tabular}{|l|c|}
\hline \multicolumn{1}{|c|}{ Nauczyciele } & Okres pracy \\
\hline Retzlaff Leonard & $1921-1927$, emeryt \\
\hline Idzikowski Józef & $1921-1937$, emeryt \\
\hline Lisakowski Teofil & $1921-1939$ \\
\hline Bieńkowski Jan & $1921-1939$ \\
\hline Lewandowski Brunon & $1921-1939$ \\
\hline Maciejewski Jan & $1921-1939$, zamordowany 1939 \\
\hline Fenske Edmund & $1921-1939$ \\
\hline Wojczyński & 1921-1939 XI 1930-1939 \\
\hline Szuttówna Elżbieta & 1 IX 1930-30 VIII 1931 \\
\hline Tobolski January & 1 IX 1931 \\
\hline Tkaczyk Eugeniusz & $1921-1927$ jako nauczyciel \\
\hline Jereczek Franciszek & 1927-1933 jako kierownik szkoły \\
\hline ks. Bartel Józef & 1927-25 IV 1933 jako katecheta \\
& 25 IV 1933 jako kierownik szkoły \\
\hline Kolasińska Aleksa & 1 III 1935 \\
\hline Kotewicz Józef & 1 IX 1937-39 powołany do służby wojennej \\
\hline
\end{tabular}

\footnotetext{
${ }^{24}$ Ośrodek..., s. 5.

25 Ibidem, s. 14.

26 Ibidem, s. 17.
} 


\begin{tabular}{|c|c|}
\hline Kamiński Józef & 16 IX 1937-1939 powołany do służby wojennej \\
\hline Szutta Jan & 1 III 1936-30 VI 1936 \\
\hline Tomaszewska Maria & 1 II 1939 - do wybuchu wojny \\
\hline Meyer Brunon & 1924-1939 wywieziony do Puław \\
\hline Wryczanka Bronisław & 1 IX 1938 \\
\hline Walentówna Bronisława & 1923-1 XI 1929 przeniesiona do Rybnika \\
\hline Wychowawcy & Okres pracy \\
\hline Strzyżewski Franciszek & 1921-1939 \\
\hline Tomaszewski & 1921-1929 \\
\hline Kamiński Władysław & 1 IV 1929-31 V 1935 \\
\hline Derc Józef & 1 III 1937-1939 \\
\hline Wychowawczynie & Okres pracy \\
\hline Gromadzka Tekla & do 30 VI 1931 \\
\hline Forszpanikówna Helena & 6 VI 1929- 31 V 1930 \\
\hline Świeczkowska Magdalena & $1 \times 1930-1$ V 1933 \\
\hline Zawadzka Wanda & 1 VIII 1931-30 XI 1931 \\
\hline Olszówna Anna & 5 XII 1931-1 V 1933 \\
\hline Piesik Zofia & 1 V 1933-1939 \\
\hline Goniszewska Marta & 1 V 1933-1939 \\
\hline Woźni & Okres pracy \\
\hline Draszanowski & 1 XI 1929-3 XII 1929 \\
\hline Frankowski Józef & 23 XII 1929-14 I 1930 \\
\hline Tesner Florian & 21 I 1930-22 I 1930 \\
\hline Beyrowski Józef & 1 II 1930-31 V 1936 \\
\hline
\end{tabular}

Źródło: J. Kotewicz, Historia Zakładu dla Głuchoniemych, maszynopis w posiadaniu Ośrodka Szkolno-Wychowawczego nr 2 dla Głuchych w Wejherowie, knlb.

\section{Dydaktyka}

W Zakładzie w Wejherowie czas nauki dla dzieci głuchoniemych określono zasadniczo na 8 lat. Starosta Krajowy mógł przedłużyć obowiązek szkolny, jednak nie dłużej niż do końca roku szkolnego, w którym wychowanek kończył 18 lat. Warunkiem uzyskania takiego przedłużenia była opinia rady pedagogicznej, według której przedłużenie nauki szkolnej dawało nadzieję na osiągnięcie przez wychowanka założonego celu dydaktycznego. Zadaniem rady pedagogicznej było m.in. układanie, wspólnie z dyrektorem placówki, programu nauczania i podziału lekcji, który za pośrednictwem starosty Krajowego był przedkładany Kuratorium. Rada pedagogiczna była również odpowiedzialna za podział uczniów na klasy i oddziały. Przyjęto zasadę, według której liczba uczniów w jednej klasie wynosi: 
- w oddziałach artykulacyjnych po 7 uczniów,

- w klasach niższych i średnich po 12 uczniów,

- w klasach wyższych po 14 uczniów.

Program nauki, ujęty w Regulaminie, uwzględniał następujące przedmioty: religia, czytanie i pisanie w języku polskim, rachunki, geografia, przyroda, fizyka i chemia, historia Polski i powszechna oraz nauka o Polsce współczesnej, slojd i prace ręczne, rysunki, gimnastyka i gry ${ }^{27}$. W początkowym okresie działalności placówki, opracowując program kształcenia, wzorowano się na doświadczeniach innych, analogicznych szkół, szczególnie niemieckich. Za nadrzędną metodę nauczania przyjęto czystą ustną metodę niemiecką, wywodzącą się z lipskiej szkoły Samuela Heinickego. W związku z tym duży nacisk w programie kształcenia kładziono na artykulację. Dlatego też plan nauczania z lat 1923-1933 przedstawiał się następująco:

Tabela 2. Plan nauczania

\begin{tabular}{|l|c|c|c|c|c|c|c|}
\hline \multirow{2}{*}{\multicolumn{1}{|c|}{ Przedmioty }} & \multicolumn{7}{|c|}{ Liczba godzin w poszczególnych klasach } \\
\cline { 2 - 8 } & I & II & III & IV & V & VI & VII \\
\hline Religia & 2 & 2 & 2 & 2 & 2 & 2 & 2 \\
\hline Język polski & & & & & & & \\
artykulacja & 6 & 2 & 2 & 2 & - & - & - \\
odczytywanie z ust & - & 2 & 2 & - & - & 3 & 3 \\
wysławianie się & - & - & 2 & 3 & 3 & 3 & 3 \\
czytanie & - & 2 & 2 & 3 & 3 & 3 & 3 \\
pisanie & - & 2 & 2 & 2 & 3 & 3 & 3 \\
\hline Rachunki & 4 & 4 & 4 & 4 & 4 & 4 & 4 \\
\hline Nauki przyrodnicze & - & - & - & - & 2 & 2 & 2 \\
\hline Historia & - & - & - & - & 2 & 2 & 2 \\
\hline Geografia & - & - & - & - & 2 & 2 & 2 \\
\hline Rysunki & 2 & 2 & 2 & 2 & 2 & 2 & 2 \\
\hline Gimnastyka & 2 & 2 & 2 & 2 & 2 & 2 & 2 \\
\hline Roboty ręczne & 2 & 2 & 2 & 2 & 2 & 2 & 2 \\
\hline Razem & 18 & 20 & 22 & 24 & 29 & 30 & 30 \\
\hline
\end{tabular}

Źródło: Historia Ośrodka Szkolno-Wychowawczego nr 2 dla Gluchych im. J. Siestrzyńskiego w Wejherowie, Wejherowo 1991, s. 22.

W Zakładzie dbano także o przygotowanie wychowanków do pracy zawodowej, którą mogli wykonywać po opuszczeniu placówki. Kształcenie zawodowe podopieczni zdobywali, szkoląc się w warsztatach: stolarskim, siodlarskim, szewskim, szwalni i drukarni28.

27 Regulamin...., s. 69.

${ }^{28}$ APGOG, Zespół 223, Krajowe Zakłady Opieki Społecznej w Wejherowie, sygn. 12, k 81-83. 


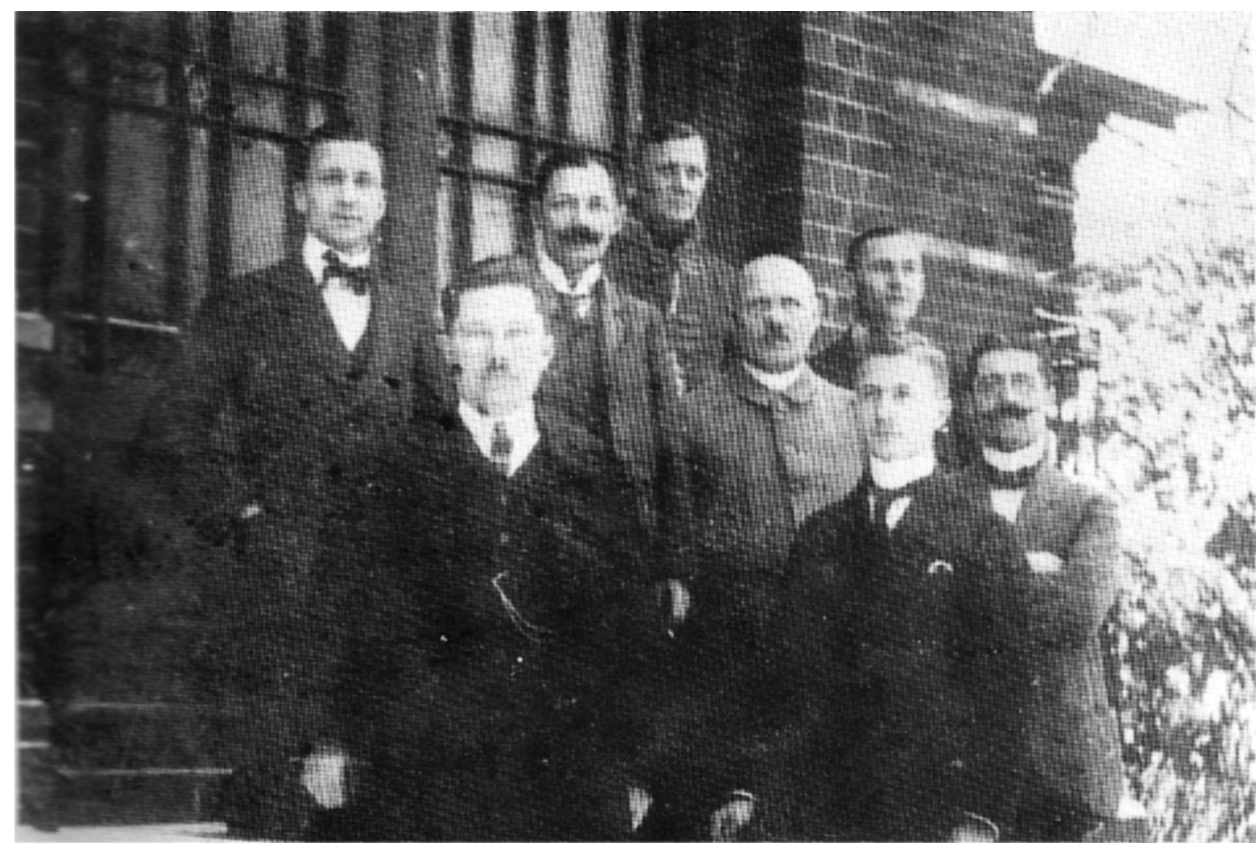

Ryc. 2. Pierwsze grono pedagogiczne Zakładu (od lewej): B. Lewandowski, T. Lisakowski, L. Retzlaff, J. Idzikowski, W. Wojczyński, E. Fenske, nad nim J. Maciejewski, J. Bieńkowski Źródło: Historia Ośrodka Szkolno-Wychowawczego nr 2 dla Gluchych im. J. Siestrzyńskiego $w$ Wejherowie, Wejherowo 1991, s. 7.

Pierwsi wychowankowie wspominali, że w Zakładzie panowała bardzo surowa dyscyplina. Uczniów obowiązywał jednolity ubiór. W czasie przerw niedozwolone były swobodne zabawy, obowiązywało chodzenie w szyku parami pod nadzorem nauczyciela. Zakład oddalony od centrum Wejherowa i otoczony wysokim murem był dla dzieci jedynym światem. Wielka żelazna brama była zwykle zamknięta, a wyjścia poza teren wymagały uzyskania specjalnej przepustki ${ }^{29}$. Powołanie w 1926 r. na stanowisko dyrektora F. Jereczka spowodowało złagodzenie dotychczasowych zasad. W 1933 r., kiedy dyrektorem został ks. J. Bartel nastąpiło dalsze łagodzenie dotychczasowych zarządzeń. Wtedy wprowadzono wolne zabawy na świeżym powietrzu, pozwolono na dowolny ubiór, chłopcom zezwolono na zabawy z piłką, także grę w piłkę nożną, umożliwiono dzieciom częstsze wyjścia do miasta.

Wraz ze złagodzeniem w Zakładzie rygoru ożywiło się życie społeczne. Po roku 1927 głuchoniemi chłopcy zorganizowali drużynę piłki nożnej, która mierzyła się z innymi drużynami szkolnymi. Nauczyciele J. Idzikowski i E. Szuttówna założyli kółko sceniczne, które występowało przy okazji różnych uroczystości. Występy organizowano nie tyl-

29 Historia..., s. 16. 


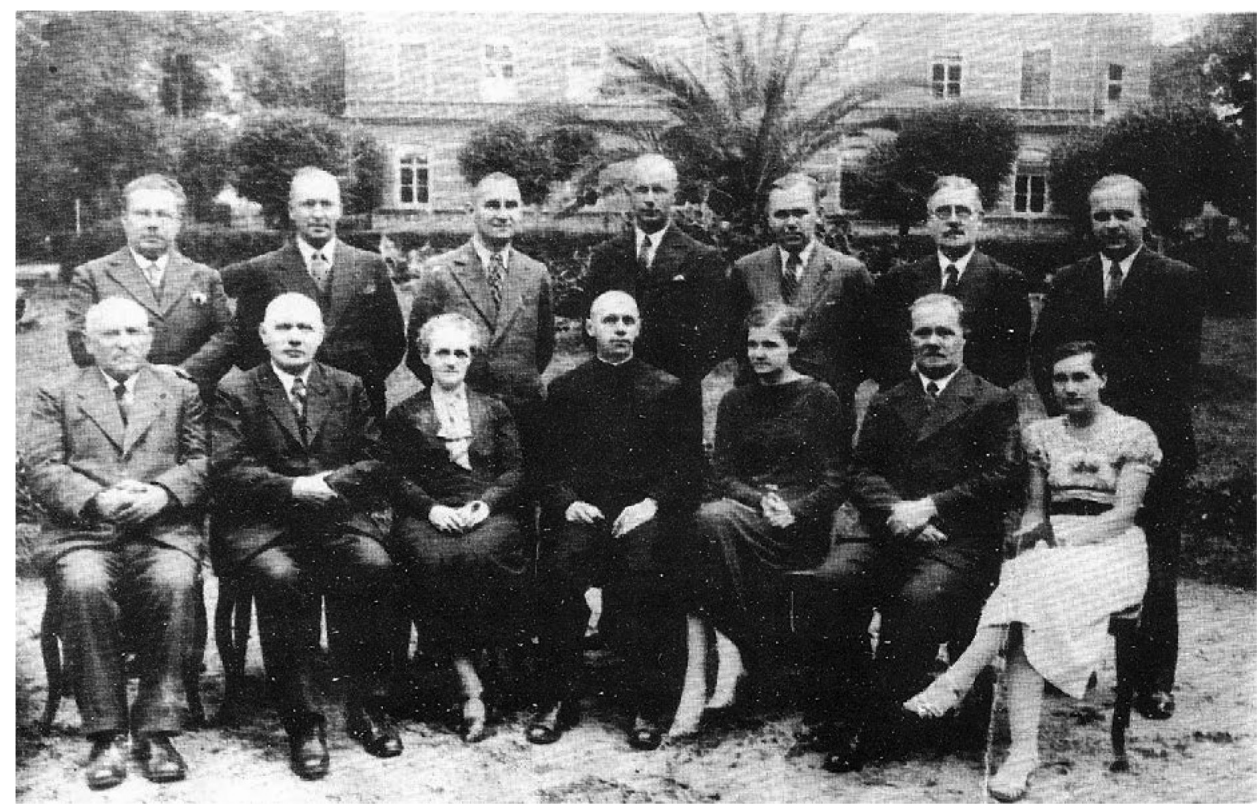

Ryc. 3. Nauczyciele szkoły w 1935 r. Od lewej stoją: Strzyżewski F., T. Lewandowski, J. Maciejewski, E. Fenske, E. Tkaczyk, J. Bieńkowski, B. Meyer. Od lewej siedzą: F. Jereczek, J. Wojczyński, S. Wojciechowska, ks. J. Bartel - kierownik szkoły, A. Kolasińska, J. Idzikowski, E. Szuttówna Źródło: Historia Ośrodka Szkolno-Wychowawczego nr 2 dla Gluchych im. J. Siestrzyńskiego w Wejherowie, Wejherowo 1991, s. 17.

ko w ,auli” zbudowanej na te potrzeby w internacie dziewcząt, ale także w publicznej sali w Wejherowie. Często organizowano także wystawy wyrobów wychowanków, które cieszyły się dużym zainteresowaniem mieszkańców miasta. Ponadto E. Szuttówna zorganizowała w placówce pierwszą drużynę harcerską, która cieszyła się dużym zainteresowaniem wychowanków. Ważnym wydarzeniem dla życia placówki było założenie i redagowanie przez nauczyciela Eugeniusza Tkaczyka gazetki szkolnej ${ }^{30}$. Po roku zastąpiła go nauczycielka Aleksa Kolasińska. Wydawanie gazetki rozpoczęto w 1933 r. pod nazwą „Gazetka Szkolna Wychowanków Szkoły dla Głuchoniemych w Wejherowie”, publikując w ciągu roku cztery numery. Niestety wydawano ja tylko przez trzy lata. Do gazetki materiały przygotowywali sami wychowankowie, a publikowana była czcionkami Drukarni Zakładu Wychowawczego w Wejherowie. Pełniła ważna funkcję dydaktyczną i wychowawczą, zachęcała bowiem do czytelnictwa, wzbogacała szkolnictwo, inspirowała do samodzielnego opisywania przeżyć31. W numerze 5 z 1934 r. znaleźć można list byłej wychowanki placówki, Leokadii Gabrychówny skierowany do redakcji „Gazetki”. Pokazuje on, jakie wspomnienia po pobycie w Zakładzie pozostawały w wychowankach:

30 J. Kotewicz, op. cit., klnb.

31 Ośrodek...., s. 8. 


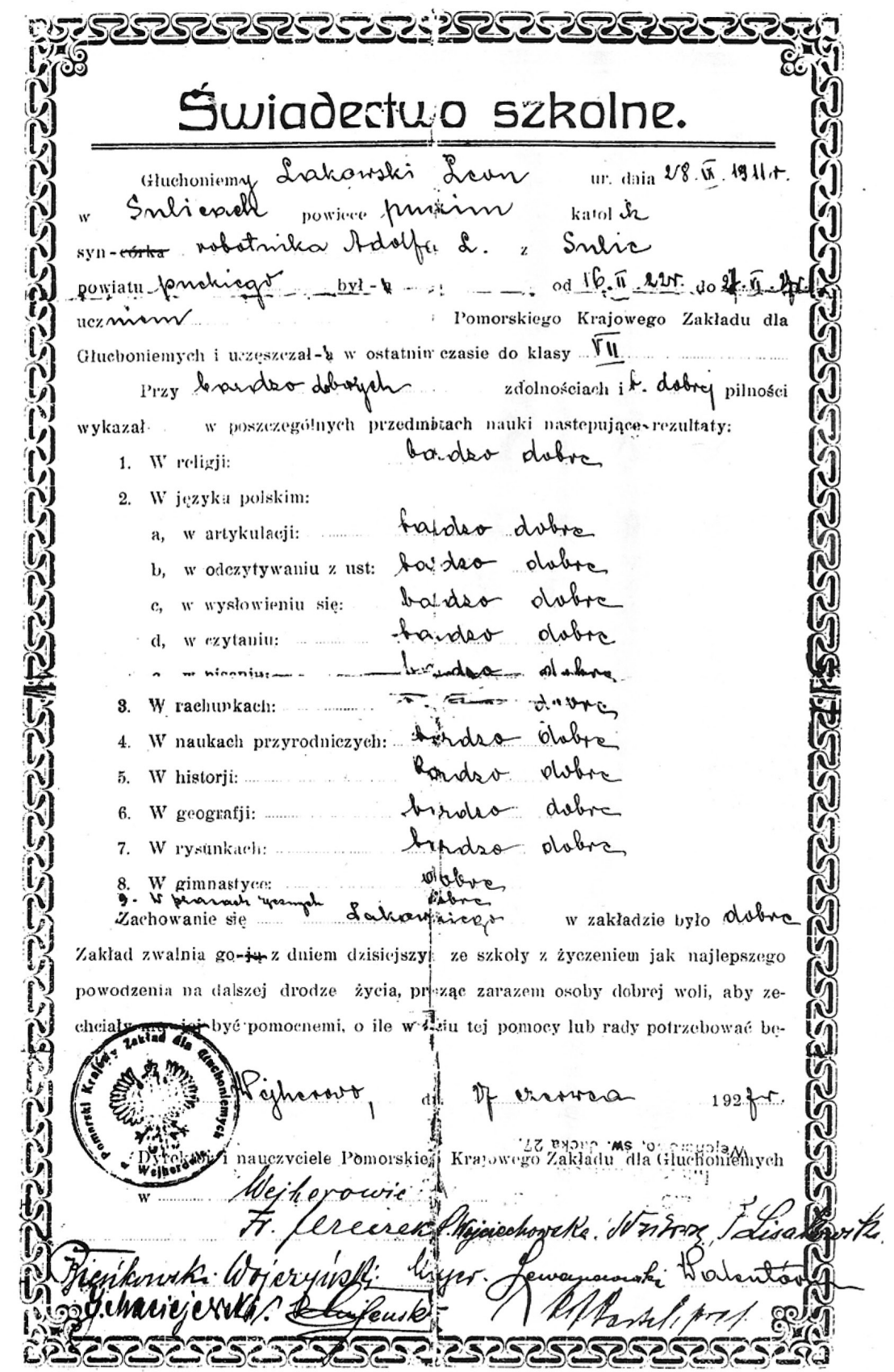

Ryc. 4. Swiadectwa szkolne

Źródło: Historia Ośrodka Szkolno-Wychowawczego nr 2 dla Gtuchych im. J. Siestrzyńskiego $w$ Wejherowie, Wejherowo 1991, s. 13. 
Dawno już miałam zamiar pisać list do kochanej „,Gazetki Szkolnej”. Niestety przesuwato się pisanie do tego czasu. W połowie stycznia br. dostała mi sie po raz pierwszy do rąk „Gazetka Szkolna". Nie baczac zabratam się do czytania jej z wielkim zainteresowaniem. Jestem bardzo zadowolona i niezmiernie się cieszę, że dużo dowiaduje się o kochanej szkole. Gdy jestem zajęta czytaniem, to zdaje mi się, jakobym była znów razem z koleżankami w szkole. Miło mi jest wspominać chwile przeżywane $w$ szkole, owych chwil $w$ życiu nigdy nie zapomnę. Do końca życia wdzięczna będę ks. Dyrektorowi, pp. Nauczycielom za doznana opieke podczas mego pobytu w szkole dla głuchoniemych. Dziękuję serdecznie za bezpłatne przesłanie egzemplarzy gazetki Katolickiemu Towarzystwu Gtuchoniemych w Czersku w celu podziatu tutejszym członkom. Prosze pozdrowić wszystkich serdecznie, a szczególnie pania nauczycielkę Wojciechowska, która mnie dobrze uczyła ${ }^{32}$.

W materiałach źródłowych zgromadzonych przez Ośrodek Szkolno-Wychowawczy zachowały się wspomnienia uczniów i nauczycieli, które zamieszczone zostały w maszynopisie nauczyciela Zakładu J. Kotewicza i częściowo opublikowane w jubileuszowym opracowaniu historii placówki. Wspomnienia te opisują naukę i życie codzienne w placówce, będąc jednocześnie oceną funkcjonowania Zakładu i jakości kadry pedagogicznej. Uczennica Klara Wittkowa tak wspomina naukę w szkole:

W roku 1921 jako glucha po ciężkiej chorobie, mając lat 6 zostatam przyjęta do nowo otwartej w tym czasie szkoły głuchych [...]. Rok szkolny rozpocząt się 1 IX 1921 r. Wkrótce po moim przybyciu nastapiło uroczyste otwarcie szkoły poprzedzone msza święta i poświęceniem budynków szkolnych dokonane przez ks. Prałata W. dąbrowskiego z Wejherowa w obecności przedstawicieli z województwa i grona nauczycielskiego z dokonaniem zdjęć pamiątkowych. Rozpoczynając pierwszy rok szkolny spośród kolegów i koleżanek byłam najmłodsza, uczyliśmy się w dużej, widnej Sali obok kancelarii. Naszym wychowawca I klasy byt pierwszy dyrektor szkoły Rectaw Leonard, człowiek o surowym obliczu i spojrzeniu, potem Lewandowski. Nauka w pierwszej klasie opierała się wytacznie na artykulacji [...], następnie na wymawianiu wyrazów, w klasie II natomiast na układaniu zdań. Była to dla nas nauka dość nudna, dla nauczyciela zaś najtrudniejsza, wymagała wiele życzliwości i wiele poświęcenia. [...] Dopiero od III klasy nauka składajaca się z coraz szerszego programu zaczęła mnie interesować, toteż z coraz większym zapałem zaczętam się uczyć osiagając coraz lepsze wyniki. Do dziś moim niezatartym wspomnieniem byt przyjazd prezydenta Polski Stanisława Wojciechowskiego do Wejherowa i przybycie jego do Pomorskiego Zaktadu dla Gluchoniemych. W tym uroczystym dniu, będac w III klasie zostaliśmy ustawieni szpalerem przy głównej bramie Zakładów. Na samym wstepie powitania dostojnego gościa na znak dany mi przez wychowawczynię klasy podeszłam do niego ubrana po krakowsku, z bukietem kwiatów w ręce i wniostam trzykrotny okrzyk; Niech nam żyje Prezydent Rzeczypospolitej Polski. Następnie starszy ode mnie Henryk Monikowski wypowiedziat wiersz na cześć dostojnego gościa. Przechodzac do dalszych klas, przedmiotem najciekawszym dla mnie była historia Polski oraz czytanka. Z wielka pasja stuchałam z ust wychowawczyni dzieje historii królów Polski, ich panowania i stoczone bitwy. Uczyłam się tego prawie na pamięć. Dla utrwalenia pamięci wisiata na ścianie klasy tablica królów Polski. Wisiały też różne obrazy, między innymi podobizny poetów polskich, obrazy obrazujące żywa przyrodę, jak rośliny, zioła, grzyby itp. Ogólnie ulubionym zajęciem były rysunki ręczne. Rysunki prowadzone były przez nauczyciela Fenskego, później przez Jereczka. W pogodnych dniach nieraz udaliśmy się z nauczycielem $w$ rękach trzymając bloczek rysunkowy $i$ ołówek do lasu i tam rysowaliśmy brzozę, grzyby i widoki leśne. W kierunku rysunku wykazywali uczniowie duże zdolności, a najzdolniejszym byt kolega Sommer-

${ }^{32}$ Historia..., s. 24. 
feld, który ołówkiem rysowat portrety poetów polskich J. Stowackiego, H. Sienkiewicza i innych pisarzy, uzyskując od zwiedzajacych pochwały. Również ulubionym zajęciem byty robótki ręczne różnorodnie wykonywane: na haftowaniu, szydełkowaniu, robieniu siatek i serwetek czółenkiem itp. Efektownie wykonane, co dobitnie świadczyło o zdolności głuchych dziewcząt i chłopców, którzy wyrabiali rzeźby z drewna, z gliny, małe kilimy i inne ciekawe, petne zachwytu eksponaty pod kierunkiem J. Idzikowskiego, a robótki u dziewcząt St. Wojciechowskiej. Eksponaty wystawione były $w$ Wejherowie na wystawie, która cieszyła się dużym zainteresowaniem ze strony zwiedzajacej publiczności i dużym popytem. Ponieważ po kilkudniowej wystawie następowała sprzedaż $i$ w pierwszym dniu sprzedaży prawie wszystkie eksponaty zostały sprzedane. Z gimnastyki korzystaliśmy pod kierunkiem nauczycielki Walentynówny na świeżym powietrzu na dziedzińcu szkoły, zima w godzinach popoludniowych w Sali miejscowego gimnazjum Jana Sobieskiego. Ogólnie najtatwiejszym przedmiotem byty rachunki. Niemal wszyscy uczniowie wymagane zadania potrafili rozwiazać. W 8-mej klasie lekcje matematyki prowadzone były przez nauczyciela Bieńkowskiego, który uczył nas obliczania procentów i ułamków wyjętych z matematyki drugiej klasy gimnazjum. Zaktad dla Gluchych otoczony naokoto wysokim murem i żelazna brama byt z reguty zamknięty, dostepny dzieciom do miasta tylko za okazaniem tak rzadko wydanej przepustki odźwiernemu. Wspólne przechadzki dzieci pod opieka wychowawcy internatu odbywaty sie $w$ każda niedzielę wytacznie w parku zakładowym, bardzo rzadko w mieście. Po objęciu stanowiska dyrektora po Rectawie przez Jereczka sytuacja nieco się zmieniła. Pozwolono ku uciesze dzieci częściej zwiedzać miasto. Przez kilka lat bywając w szkole miałam możność poznać charakter mojej wychowawczyni klasy Stefanii Wojciechowskiej. Była to kobieta szczerze oddana sprawie głuchych, z petnym poświęceniem starała się uczniów wzbogacić nauka $i$ wpoić uczucie patriotyzmu. Za lenistwo surowo karała, a za dobre wywiazywanie się z nauki nagradzała podarunkami w postaci ksiażek do czytania. Przed zakończeniem roku szkolnego w VIII klasie każdy otrzymat od wychowawczyni klasy na pamiątke pięknie oprawiona ksiażkę historyczna pt. Wieczory pod lipa. W okresie szkolnym dostojnymi gośćmi byli ks. Biskup Okoniewski z Pelplina i ks. Kardynat Hlond z Poznania. W czasie odwiedzin wymienionych gości zebrano się w auli, gdzie przy ustawionych pulpitach szkolnych prowadzono lekcje niektórych klas. Naszej klasie przypadt również udziat. Co rok gośćmi naszej klasy byli absolwenci miejscowego Seminarium Nauczycielskiego i jako młodzi przyszli nauczyciele uważnie wystuchiwali przeprowadzonych lekcji w kilku klasach, twierdzac, że nauczanie gtuchych jest niezwykle trudne, nie pobudzajace chęci na stanowisko nauczyciela głuchych. Od czasu do czasu odwiedzat nasza klase dr Sokołowski lekarz zakladowy, u którego w gabinecie lekarskim przechodziliśmy nieraz badanie. Organizowane były co pewien czas przedstawienia widowiskowe $w$ auli odgrywane przez uczniów pod kierownictwem nauczycieli Wojciechowskiej i Idzikowskiego. Najprzyjemniejszym dla mnie wspomnieniem okresu szkolnego byto wręczenie mi prezentu od wojewody pomorskiego w formie obrazu przedstawiającego Królowa Korony Polskiej za pilność i dobre zachowanie się. Obraz ten do dzisiaj jest w moim posiadaniu. $W$ dniu zakończenia szkoty $w$ czerwcu 1929 r., gdzie $w$ auli na pożegnaniu w obecności zaproszonych gości, rodziców i krewnych uczniów czasie pożegnalnego przemówienia dyrektora szkoły Jereczka wymówione zostały pochwały dla najlepszych uczniów i wśród nich padto również i moje nazwisko, zobaczyłam uradowane twarze rodziców ${ }^{33}$.

Warto podkreślić, że Zakład dla Głuchoniemych w Wejherowie zajmował się także swoimi byłymi wychowankami w późniejszym ich życiu. W tym celu prowadził dokładną ewidencję uczniów opuszczających placówkę. W Regulaminie Zakładu znajduje się zapis: Dla dorostych głuchoniemych obojga płci, którzy z powodu ułomności fizycznej nie byli $w$ stanie zarobić na własne utrzymanie oraz takich którym grozit upadek moralny

\footnotetext{
33 J. Kotewicz, op. cit., knlb.
} 
należy utworzyć przy zakładzie schronisko, którym kieruje dyrektor zakładu. Za utrzymanie płaca gminy przynależne 180 zt rocznie. O przyjęciu do schroniska decyduje na wniosek gminy Starosta Krajowy. Raz w roku w czasie wakacyjnym urządza się w Zakładzie dla Gtuchoniemych dwudniowe zjazdy zamieszkałych na Pomorzu głuchoniemych. Zjazdy te maja na celu uświadamianie i umoralnienie tych głuchoniemych. Zjazdem kieruje dyrektor zakładu wspólnie z księdzem katecheta oraz rada pedagogiczna. Podczas zjazdu udziela zakład głuchoniemym bezpłatnie noclegu $i$ wyżywienia. W celach duszpasterstwa urzadza w czasie wakacyjnym ksiadz katecheta zjazdy okręgowe dorostych gtuchoniemych zamieszkałych na Pomorzu $u^{34}$. Niestety w analizowanych materiałach źródłowych nie znaleziono informacji, które potwierdziłyby realizację zapisów Regulaminu. Dlatego konieczne są dalsze badania, zwłaszcza okresu dwudziestolecia międzywojennego, które pozwolą być może na szczegółowsze zaprezentowanie opisywanej instytucji, zwłaszcza działalności dydaktycznej, wychowawczej, jej efektywności oraz kadry pedagogicznej.

\section{Bibliografia}

\section{Źródła archiwalne}

Archiwum Państwowe w Gdańsku Oddział w Gdyni:

Zespół 223: Krajowe Zakłady Opieki Społecznej w Wejherowie, sygn. 3, 9, 12.

Zespół 72, Inspektorat Szkolny w Wejherowie z lat [1911] 1918-1939, sygn. 343.

\section{Źródła drukowane}

Regulamin dla Pomorskiego Krajowego Zakładu dla Gtuchoniemych w Wejherowie, Dziennik Urzędowy Województwa Pomorskiego, nr 15, rok V, Toruń, 13. VI, 192.

Kotewicz J., Historia Zakładu dla Głuchych w Wejherowie. Maszynopis w posiadaniu Biblioteki Ośrodka Szkolno-Wychowawczego nr 2 w Wejherowie.

Historia Ośrodka Szkolno-Wychowawczego nr 2 dla Gluchych im. J. Siestrzyńskiego w Wejherowie, Wejherowo 1991.

Ośrodek Szkolno-Wychowawczy nr 2 dla Niestyszących im. J. Siestrzyńskiego w Wejherowie, Wejherowo 2001.

\section{Czasopisma}

Statystyka, Nauczyciel Głuchoniemych i Niewidomych"1928, nr 2.

Tułodziecki W., Stan i potrzeby szkolnictwa dla głuchoniemych w Polsce, „Nauczyciel Głuchoniemych i Niewidomych" 1932, nr 1.

Hellmann J., Stan i potrzeby szkolnictwa specjalnego w Polsce, ,Szkoła Specjalna” 1924/25, nr 1. Ryll H., Stan szkolnictwa specjalnego w Polsce w ostatnim pięcioleciu, „Szkoła Specjalna” $1938 / 39$, nr 15, s. 153-155.

\footnotetext{
${ }^{34}$ Regulamin..., s. 70
} 